\title{
A Modified Method for the Accurate Determination of Chemical Oxygen Demand (COD) in High Chloride Oilfield Wastewater
}

\author{
Shanhui Zhang, Wu Chen, Yang Liu, Pengfei Luo, Huiwen Gu* \\ State Key Laboratory of Petroleum Pollution Control, College of Chemistry and Environmental Engineering, Yangtze University, \\ Jingzhou, China \\ Email: *gruyclewee@yangtzeu.edu.cn
}

How to cite this paper: Zhang, S.H., Chen, W., Liu, Y., Luo, P.F. and Gu, H.W. (2018) A Modified Method for the Accurate Determination of Chemical Oxygen Demand (COD) in High Chloride Oilfield Wastewater. Open Journal of Yangtze Gas and Oil, 3, 263-277.

https://doi.org/10.4236/ojogas.2018.34023

Received: March 22, 2018

Accepted: October 26, 2018

Published: October 29, 2018

Copyright (C) 2018 by authors and Scientific Research Publishing Inc. This work is licensed under the Creative Commons Attribution International License (CC BY 4.0).

http://creativecommons.org/licenses/by/4.0/

\begin{abstract}
In this work, in order to find a method for the accurate determination of chemical oxygen demand $\left(\mathrm{COD}_{\mathrm{Cr}}\right)$ in high chloride oilfield wastewater, the interferences of chloridion $\left(\mathrm{Cl}^{-}\right)$on $\mathrm{COD}_{\mathrm{Cr}}$ determination were first studied based on the Chinese national standard GB 11914-89. The results showed that the $\mathrm{COD}_{\mathrm{Cr}}$ values and deviations determined by the classical potassium dichromate $\left(\mathrm{K}_{2} \mathrm{Cr}_{2} \mathrm{O}_{7}\right)$ method increased gradually with the increase of $\mathrm{Cl}^{-}$mass concentration in water samples. Then, theoretical and experimental studies on reducing interferences of $\mathrm{Cl}^{-}$on $\mathrm{COD}_{\mathrm{Cr}}$ determination were carried out. The results showed that different concentrations of $\mathrm{K}_{2} \mathrm{Cr}_{2} \mathrm{O}_{7}$ exhibited different oxidation capacities on $\mathrm{Cl}^{-}$, while having little effects on the oxidation of organic compounds. More specifically, when the concentration of $\mathrm{K}_{2} \mathrm{Cr}_{2} \mathrm{O}_{7}$ was $0.025 \mathrm{~mol} \cdot \mathrm{L}^{-1}$ and the mass ratio of $\mathrm{HgSO}_{4}: \mathrm{Cl}^{-}$was $10: 1$, the interferences of $\mathrm{Cl}^{-}$on $\mathrm{COD}_{\mathrm{Cr}}$ determination were the slightest. Finally, a low concentration oxidant method was proposed for the accurate determination of $\mathrm{COD}_{\mathrm{Cr}}$ in high chloride oilfield wastewaters. The performances of the proposed method were verified by the simulated and actual high chloride oilfield wastewater. The results showed that when $\mathrm{Cl}^{-} \leq 20,000 \mathrm{mg} \cdot \mathrm{L}^{-1}$ and $\mathrm{COD}<100$ $\mathrm{mg} \cdot \mathrm{L}^{-1}$, the relative prediction errors of $\mathrm{COD}_{\mathrm{Cr}}$ provided by the proposed method were acceptable, which revealed that the low concentration oxidant method is feasible and reliable for the determination of $\mathrm{COD}_{\mathrm{Cr}}$ in high chloride oilfield wastewater.
\end{abstract}

\section{Keywords}

High Chloride Oilfield Wastewater, Chloridion Interference, Chemical Oxygen Demand, Potassium Dichromate Method, Low Concentration Oxidant Method 


\section{Introduction}

Chemical oxygen demand (COD) is one of the most important indexes to assess the pollution of organic compounds in water systems [1]. In China, potassium dichromate $\left(\mathrm{K}_{2} \mathrm{Cr}_{2} \mathrm{O}_{7}\right)$ method is legalized by the Chinese government to determine $\mathrm{COD}_{\mathrm{Cr}}$ in water samples [2] [3]. In practical operation, the high level of chloridion $\left(\mathrm{Cl}^{-}\right)$in water samples would cause serious interferences on $\mathrm{COD}_{\mathrm{Cr}}$ determination [4] [5]. Therefore, the Chinese national standard method Water Quality-Determination of Chemical Oxygen Demand-Dichromate Method (GB 11914-89) regulated that when the content of $\mathrm{Cl}^{-}$is less than $1000 \mathrm{mg} \cdot \mathrm{L}^{-1}$, mercuric sulfate $\left(\mathrm{HgSO}_{4}\right)$ can be added to eliminate the interferences of $\mathrm{Cl}^{-}$[6]. For the samples with $\mathrm{Cl}^{-}$content more than $1000 \mathrm{mg} \cdot \mathrm{L}^{-1}$, they should be firstly diluted quantitatively so as to reduce their $\mathrm{Cl}^{-}$contents to less than $1000 \mathrm{mg} \cdot \mathrm{L}^{-1}$ and then determine their $\mathrm{COD}_{\mathrm{Cr}}$ according to the Chinese national standard GB 11914-89. Research revealed that, the COD values of water samples with high $\mathrm{Cl}^{-}$ concentration and low $\mathrm{COD}$ content were still large after diluting, although $\mathrm{HgSO}_{4}$ was used to mask $\mathrm{Cl}^{-}$, and the relative errors of $\mathrm{COD}_{\mathrm{Cr}}$ increased with the increase of $\mathrm{Cl}^{-}$concentration. However, during the process of monitoring and analysis, the high chloride wastewaters are often encountered, such as chemical wastewater, marine products processing wastewater, rare-earth mineral refining wastewater, oil produced wastewater. For example, Chen et al. [7] reported that the mass concentration of $\mathrm{Cl}^{-}$in wastewater of an oilfield was more than 120000 $\mathrm{mg} \cdot \mathrm{L}^{-1}$, whose COD content was low, and the COD values would become smaller after treatment. But the local environmental protection department used the Chinese national standard GB 11914-89 to monitor its COD concentration with results fluctuating significantly and gave the actual measured $\mathrm{COD}_{\mathrm{Cr}}$ values ranging from several hundreds to $2500 \mathrm{mg} \cdot \mathrm{L}^{-1}$, which greatly exceeded the national requirements of wastewater discharge (COD $\left.<100 \mathrm{mg} \cdot \mathrm{L}^{-1}\right)$ [8]. This dilemma brings huge troubles to the wastewater disposal departments, local environmental monitoring and law enforcement departments as well as the water quality analysis workers. Therefore, how to eliminate the interferences of $\mathrm{Cl}^{-}$on the $\mathrm{COD}_{\mathrm{Cr}}$ determination has become a research hot for environmental monitoring workers [9].

At present, there are many methods for reducing the interferences of $\mathrm{Cl}^{-}$, such as chlorine correction method, low concentration oxidant method, silver salt precipitation method, sealed digestion method, mercury salt method and no external heating method [10] [11] [12] [13] [14], which have not yet been unified. However, in the practical operations of the environmental monitoring department, the national or industrial standards recommended by the Chinese Ministry of Environmental Protection are still used as the reference method. Among them, potassium dichromate method (GB 11914-89, abbreviated as the classical method) [6] is the mandatory national standard, whereas fast digestion-spectrophotometric method (HJ/T 399-2007) [15], chlorine correction method (HJ/T 70-2001) [16] and potassium iodide-alkaline potassium permanganate determination method (HJ/T 132-2003) [17] are the standards released by the National 
Environmental Protection Department, which are the supplements to the national standard, and whose legal status are naturally lower than that of the classical method (GB 11914-89) [6]. Consequently, during the supervision of law enforcement, the COD determination of samples with high requirements such as discharge sample, assessment sample, arbitration analysis sample is preferred by the classical method (GB 11914-89).

Considering the current research situation mentioned above, the aim of the work is to develop a method that can meet the national standard, and can accurately determine the $\mathrm{COD}_{\mathrm{Cr}}$ in wastewaters with high content of $\mathrm{Cl}^{-}$. In this work, the interferences of $\mathrm{Cl}^{-}$on $\mathrm{COD}_{\mathrm{Cr}}$ determination were first investigated by experiments based on the Chinese national standard GB 11914-89, and then the mechanism of interferences was explained. After that, based on the theoretical analysis of electrode potential, a low concentration oxidant method was proposed for the determination of $\mathrm{COD}_{\mathrm{Cr}}$ in high chloride wastewaters. The performances of the proposed method were verified by simulated and actual high chloride oilfield wastewater. The results demonstrated that the proposed low concentration oxidant method based on GB 11914-89 was accurate and reliable, and thus it is a feasible method for the determination of $\mathrm{COD}_{\mathrm{Cr}}$ in high chloride oilfield wastewater.

\section{Experimental Section}

\subsection{Reagents and Instruments}

Reagents: potassium dichromate solution $\left(1 / 6 \mathrm{~K}_{2} \mathrm{Cr}_{2} \mathrm{O}_{7}\right)$ with concentrations of $0.25 \mathrm{~mol} \cdot \mathrm{L}^{-1}, 0.10 \mathrm{~mol} \cdot \mathrm{L}^{-1}$ and $0.025 \mathrm{~mol} \cdot \mathrm{L}^{-1}$; ammonium ferrous sulfate solution $\left[\left(\mathrm{NH}_{4}\right)_{2} \mathrm{Fe}\left(\mathrm{SO}_{4}\right)_{2} \cdot 6 \mathrm{H}_{2} \mathrm{O}\right]$ with concentrations of $0.1 \mathrm{~mol} \cdot \mathrm{L}^{-1}, 0.04 \mathrm{~mol} \cdot \mathrm{L}^{-1}$ and 0.01 mol. $\mathrm{L}^{-1}$; mercury sulfate $\left(\mathrm{HgSO}_{4}\right.$, A.R.), silver sulfate $\left(\mathrm{Ag}_{2} \mathrm{SO}_{4}\right.$, A.R.); sulfuric acid $\left(\mathrm{H}_{2} \mathrm{SO}_{4}, 98 \%\right)$; seven hydrated ferrous sulfate $\left(\mathrm{FeSO}_{4} \cdot 7 \mathrm{H}_{2} \mathrm{O}\right.$, A.R.); standard potassium acid phthalate $\left(\mathrm{KC}_{8} \mathrm{H}_{5} \mathrm{O}_{4}, \mathrm{G} . \mathrm{R}.\right)$; sodium chloride $(\mathrm{NaCl}, \mathrm{A} . \mathrm{R}$.$) ;$ 1,10-phenanthroline. All these reagents were purchased from the Sinopharm Chemical Reagent Co., Ltd. and used without further purification (Shanghai, China).

Instruments: JH-12 COD constant temperature heater (Laoshan Electronic General Factory Co., Ltd., Qingdao, China); ICS-2100 ion chromatography (Thermo Fisher Scientific, U.S.A ).

\subsection{Experimental Methods}

1) Classical $\mathrm{K}_{2} \mathrm{Cr}_{2} \mathrm{O}_{7}$ method: this classical method was described in detailed in the Chinese national standard Water Quality-Determination of Chemical Oxygen Demand-Dichromate Method (GB 11914-89) [6]. Before determination, the method was calibrated by the standard solution of $\mathrm{KC}_{8} \mathrm{H}_{5} \mathrm{O}_{4}$ with a reference $\mathrm{COD}_{\mathrm{Cr}}$ of $500 \mathrm{mg} \cdot \mathrm{L}^{-1}$ for 5 times, giving the relative errors of $\mathrm{COD}_{\mathrm{Cr}}$ less than $4 \%$, which indicated that the operation technique, instrument and chemical reagents used in this work meet the requirements. 
2) Low concentration oxidant method: this method was modified based on the classical standard method described above. More specifically, during the $\mathrm{COD}_{\mathrm{Cr}}$ determination, $0.1 \mathrm{~mol} \cdot \mathrm{L}^{-1}$ or $0.025 \mathrm{~mol} \cdot \mathrm{L}^{-1}$ of $1 / 6 \mathrm{~K}_{2} \mathrm{Cr}_{2} \mathrm{O}_{7}$ standard solution was used instead of $0.25 \mathrm{~mol} \cdot \mathrm{L}^{-1}$ of $1 / 6 \mathrm{~K}_{2} \mathrm{Cr}_{2} \mathrm{O}_{7}$ standard solution as the oxidant, whose residual content was then back titrated by corresponding $0.04 \mathrm{~mol} \cdot \mathrm{L}^{-1}$ and $0.01 \mathrm{~mol} \cdot \mathrm{L}^{-1}$ of $\left[\left(\mathrm{NH}_{4}\right)_{2} \mathrm{Fe}\left(\mathrm{SO}_{4}\right)_{2} \cdot 6 \mathrm{H}_{2} \mathrm{O}\right]$ standard solution, respectively.

\section{Results and Discussion}

\subsection{Interferences of $\mathrm{Cl}^{-}$on $\mathrm{COD}_{\mathrm{Cr}}$ Determination in Simulated High Chloride Oilfield Wastewater}

\subsubsection{Determination of High $\mathrm{COD}_{\mathrm{Cr}}$ in Simulated High Chloride Oilfield Wastewater by Classical $\mathrm{K}_{2} \mathrm{Cr}_{2} \mathrm{O}_{7}$ Method}

A series of standard water samples with a theoretical $\mathrm{COD}_{\mathrm{Cr}}$ value of $500 \mathrm{mg} \cdot \mathrm{L}^{-1}$ and $\mathrm{Cl}^{-}$mass concentrations of 100,500,1000, 2000, 4000, 8000, 10,000, 15,000 and $20,000 \mathrm{mg} \cdot \mathrm{L}^{-1}$ were prepared as simulated high chloride oilfield wastewater by using standard $\mathrm{KC}_{8} \mathrm{H}_{5} \mathrm{O}_{4}$ and standard $\mathrm{NaCl}$. According to the classical $\mathrm{K}_{2} \mathrm{Cr}_{2} \mathrm{O}_{7}$ method, $20 \mathrm{~mL}$ of each water sample was transferred into a COD digestion tube, then $0.4 \mathrm{~g} \mathrm{HgSO}_{4}$ and $30 \mathrm{~mL} \mathrm{AgSO}_{4}-\mathrm{H}_{2} \mathrm{SO}_{4}$ were added to the sample solution, and finally the mixture of each water was oxidized with $10 \mathrm{~mL}$ of 0.25 mol. $\mathrm{L}^{-1} \mathrm{~K}_{2} \mathrm{Cr}_{2} \mathrm{O}_{7}$ standard solution. After heating reflux for about $2 \mathrm{~h}$, the residual content of $\mathrm{K}_{2} \mathrm{Cr}_{2} \mathrm{O}_{7}$ was back titrated by corresponding $0.1 \mathrm{~mol} \cdot \mathrm{L}^{-1}$ $\left[\left(\mathrm{NH}_{4}\right)_{2} \mathrm{Fe}\left(\mathrm{SO}_{4}\right)_{2} \cdot 6 \mathrm{H}_{2} \mathrm{O}\right]$ standard solution. The obtained $\mathrm{COD}_{\mathrm{Cr}}$ results in the prepared water samples are summarized in Table 1.

Table 1. Results of determination of high chlorine and high COD $\left(500 \mathrm{mg} \cdot \mathrm{L}^{-1}\right)$ standard water samples by classical $\mathrm{K}_{2} \mathrm{Cr}_{2} \mathrm{O}_{7}$ method.

\begin{tabular}{cccccc}
\hline $\begin{array}{c}\text { Sample } \\
\text { No. }\end{array}$ & $\begin{array}{c}\mathrm{KC}_{8} \mathrm{H}_{5} \mathrm{O}_{4} \\
\text { theoretical COD } /\left(\mathrm{mg} \cdot \mathrm{L}^{-1}\right)\end{array}$ & $\begin{array}{c}\mathrm{Cl}^{-} \\
\left.\text {content/(mg. } \mathrm{L}^{-1}\right)\end{array}$ & $\begin{array}{c}\text { Dilution } \\
\text { fold }\end{array}$ & $\begin{array}{c}\text { Found } \\
\mathrm{COD} /\left(\mathrm{mg} \cdot \mathrm{L}^{-1}\right)\end{array}$ & $\begin{array}{c}\text { Relative } \\
\text { error/\% }\end{array}$ \\
\hline 1 & 500 & 100 & 1 & 507.3 & 1.5 \\
2 & 500 & 500 & 1 & 498.7 & -0.3 \\
3 & 500 & 1000 & 1 & 509.3 & 1.9 \\
4 & 500 & 2000 & 1 & 528.4 & 5.7 \\
5 & 500 & 4000 & 2 & 602.5 & 20.5 \\
6 & 500 & 8000 & 4 & 795.8 & 59.2 \\
7 & 500 & 15,000 & 8 & 961.4 & 92.3 \\
8 & 500 & 20,000 & 10 & 1291.1 & 158.2 \\
\hline
\end{tabular}

As can be seen from Table 1, for the simulated high chloride oilfield wastewater samples with a theoretical $\mathrm{COD}_{\mathrm{Cr}}$ of $500 \mathrm{mg} \cdot \mathrm{L}^{-1}$ and high level of $\mathrm{Cl}^{-}$, when the mass concentration of $\mathrm{Cl}^{-}$was less than $2000 \mathrm{mg} \cdot \mathrm{L}^{-1}$, the relative errors of $\mathrm{COD}_{\mathrm{Cr}}$ determined by the classical $\mathrm{K}_{2} \mathrm{Cr}_{2} \mathrm{O}_{7}$ method were relatively small (< $5.7 \%)$, which almost accorded with the national requirements that the relative error of $\mathrm{COD}_{\mathrm{Cr}}$ determination should be within $\pm 5 \%$ [18] [19]. This is because 
the addition of $0.4 \mathrm{~g} \mathrm{HgSO}_{4}$ in $20 \mathrm{~mL}$ water samples was perfectly able to coordinate $2000 \mathrm{mg} \cdot \mathrm{L}^{-1} \mathrm{Cl}^{-}$in wastewater, and then the interferences of $\mathrm{Cl}^{-}$on $\mathrm{COD}_{\mathrm{Cr}}$ determination can be virtually eliminated. However, with the increase of $\mathrm{Cl}^{-}$mass concentration in water samples, the $\mathrm{Cl}^{-}$in water samples could not be completely coordinated by $0.4 \mathrm{~g} \mathrm{HgSO}_{4}$, resulting in the obtained concentration of $\mathrm{COD}_{\mathrm{Cr}}$ in water samples increased gradually, and the differences between the experimental values and theoretical ones also increased gradually. All the above results indicated that pseudo $\mathrm{COD}_{\mathrm{Cr}}$ was introduced during the determination of $\mathrm{COD}_{\mathrm{Cr}}$ in high chloride wastewater by the classical $\mathrm{K}_{2} \mathrm{Cr}_{2} \mathrm{O}_{7}$ method. As a result, if the interferences of $\mathrm{Cl}^{-}$cannot be effectively eliminated, the obtained inaccurate $\mathrm{COD}_{\mathrm{Cr}}$ results will cause wrong expert conclusion for water quality.

\subsubsection{Determination of Low $\operatorname{COD}_{\mathrm{Cr}}$ in Simulated High Chloride Oilfield Wastewater by Classical $\mathrm{K}_{2} \mathrm{Cr}_{2} \mathrm{O}_{7}$ Method}

A series of standard water samples with a theoretical $\mathrm{COD}_{\mathrm{Cr}}$ value of $100 \mathrm{mg} \cdot \mathrm{L}^{-1}$ and $\mathrm{Cl}^{-}$mass concentrations of 100, 500, 1000, 2000, 4000, 8000, 10,000, 15,000 and $20,000 \mathrm{mg} \cdot \mathrm{L}^{-1}$ were prepared as simulated high chloride oilfield wastewater by using standard $\mathrm{KC}_{8} \mathrm{H}_{5} \mathrm{O}_{4}$ and standard $\mathrm{NaCl}$. According to the classical $\mathrm{K}_{2} \mathrm{Cr}_{2} \mathrm{O}_{7}$ method, $20 \mathrm{~mL}$ of each water sample was transferred into a COD digestion tube, then $0.4 \mathrm{~g} \mathrm{HgSO}_{4}$ and $30 \mathrm{~mL} \mathrm{AgSO}_{4}-\mathrm{H}_{2} \mathrm{SO}_{4}$ were added to the sample solution, and finally the mixture of each water was oxidized with $10 \mathrm{~mL}$ of 0.25 mol. $\mathrm{L}^{-1} \mathrm{~K}_{2} \mathrm{Cr}_{2} \mathrm{O}_{7}$ standard solution. After heating reflux for about $2 \mathrm{~h}$, the residual content of $\mathrm{K}_{2} \mathrm{Cr}_{2} \mathrm{O}_{7}$ was back titrated by corresponding $0.1 \mathrm{~mol} \cdot \mathrm{L}^{-1}$ $\left[\left(\mathrm{NH}_{4}\right)_{2} \mathrm{Fe}\left(\mathrm{SO}_{4}\right)_{2} \cdot 6 \mathrm{H}_{2} \mathrm{O}\right]$ standard solution. The obtained $\mathrm{COD}_{\mathrm{Cr}}$ results in the prepared water samples are summarized in Table 2.

Table 2. Results of determination of high chlorine and low COD (100 mg. $\left.\mathrm{L}^{-1}\right)$ standard water samples by classical $\mathrm{K}_{2} \mathrm{Cr}_{2} \mathrm{O}_{7}$ method.

\begin{tabular}{cccccc}
\hline $\begin{array}{c}\text { Sample } \\
\text { No. }\end{array}$ & $\begin{array}{c}\mathrm{KC}_{8} \mathrm{H}_{5} \mathrm{O}_{4} \\
\left.\text { theoretical COD/(mg. } \mathrm{L}^{-1}\right)\end{array}$ & $\begin{array}{c}\mathrm{Cl}^{-} \\
\left.\text {content/(mg. } \mathrm{L}^{-1}\right)\end{array}$ & $\begin{array}{c}\text { Dilution } \\
\text { fold }\end{array}$ & $\begin{array}{c}\text { Found } \\
\mathrm{COD} /\left(\mathrm{mg} \cdot \mathrm{L}^{-1}\right)\end{array}$ & $\begin{array}{c}\text { Relative } \\
\text { error/\% }\end{array}$ \\
\hline 1 & 100 & 100 & 1 & 100.0 & 0 \\
2 & 100 & 500 & 1 & 108.0 & 8.0 \\
3 & 100 & 1000 & 1 & 113.7 & 13.7 \\
4 & 100 & 2000 & 1 & 175.9 & 75.9 \\
5 & 100 & 4000 & 1 & 324.3 & 224.3 \\
6 & 100 & 8000 & 1 & 627.3 & 527.3 \\
7 & 100 & 15,000 & 1 & 981.6 & 881.6 \\
8 & 100 & 20,000 & 1 & 981.6 & 881.6 \\
\hline
\end{tabular}

As can be seen from Table 2, for the simulated high chloride oilfield wastewater samples with a theoretical $\mathrm{COD}_{\mathrm{Cr}}$ of $100 \mathrm{mg} \cdot \mathrm{L}^{-1}$ and high level of $\mathrm{Cl}^{-}$, when the mass concentration of $\mathrm{Cl}^{-}$was less than $500 \mathrm{mg} \cdot \mathrm{L}^{-1}$, the relative errors of $\mathrm{COD}_{\mathrm{Cr}}$ determined by the classical $\mathrm{K}_{2} \mathrm{Cr}_{2} \mathrm{O}_{7}$ method almost conformed to the allowable error range required by the Chinese government. But with the increase 
of $\mathrm{Cl}^{-}$mass concentration in water samples, not only the $\mathrm{COD}_{\mathrm{Cr}}$ values determined by the classical $\mathrm{K}_{2} \mathrm{Cr}_{2} \mathrm{O}_{7}$ method increased gradually, but also the differences between the experimental values and theoretical ones increased gradually. And the relative errors obtained in low COD water samples are more remarkable than those of high COD water samples as described in Section 3.1.1, which is mainly due to the higher relative concentration of $\mathrm{Cl}^{-}$in low COD water samples than those in high COD water samples under the same mass concentration of $\mathrm{Cl}^{-}$. Therefore, it is very necessary for pollutant discharging companies, environmental monitoring and legislation departments to develop a method for the accurate determination of COD in high chloride wastewater.

\subsubsection{Analysis of Interference Mechanism}

At present, the classical $\mathrm{K}_{2} \mathrm{Cr}_{2} \mathrm{O}_{7}$ method (GB 11914-89) is used to determine $\mathrm{COD}$ in water sample by concentrated $\mathrm{H}_{2} \mathrm{SO}_{4}$-assisted heating reflux. During the reaction process, not only organic compounds but also $\mathrm{Cl}^{-}$in water sample were oxidized by $\mathrm{K}_{2} \mathrm{Cr}_{2} \mathrm{O}_{7}$. The interferences of $\mathrm{Cl}^{-}$are mainly attributed to the following two aspects:

1) Consumption of oxidant $\mathrm{K}_{2} \mathrm{Cr}_{2} \mathrm{O}_{7}$

Regarding water sample containing $\mathrm{Cl}^{-}$, apart from the reaction between organic compounds and $\mathrm{K}_{2} \mathrm{Cr}_{2} \mathrm{O}_{7}$, the $\mathrm{Cl}^{-}$can be also oxidized by $\mathrm{K}_{2} \mathrm{Cr}_{2} \mathrm{O}_{7}$ and thus consumes some oxidants, which will affect the accuracy of COD determination. The corresponding reaction equation about $\mathrm{Cl}^{-}$in the water sample can be expressed as follows:

$$
2 \mathrm{Cl}^{-}+\frac{1}{2} \mathrm{O}_{2} \rightarrow \mathrm{Cl}_{2}+[\mathrm{O}]^{2-}
$$

Theoretically, $0.226 \mathrm{mg}$ oxygen is needed for complete oxidation of $1 \mathrm{mg} \mathrm{Cl}^{-}$ $[15.999 /(2 \times 35.453)=0.226]$. Taking the above reason into account, $\mathrm{Cl}^{-}$can cause huge positive interferences on $\mathrm{COD}_{\mathrm{Cr}}$ determination because of its consumption of oxidant $\mathrm{K}_{2} \mathrm{Cr}_{2} \mathrm{O}_{7}$ under the condition of Chinese national standard GB 11914-89.

2) Consumption of catalyst $\mathrm{Ag}_{2} \mathrm{SO}_{4}$

In the mixture system of $\mathrm{H}_{2} \mathrm{SO}_{4}-\mathrm{K}_{2} \mathrm{Cr}_{2} \mathrm{O}_{7}$, acidified $\mathrm{K}_{2} \mathrm{Cr}_{2} \mathrm{O}_{7}$ can just oxidize most of the organic compounds in the water sample. Only after adding catalyst $\mathrm{Ag}_{2} \mathrm{SO}_{4}$, can the straight chain aliphatic compounds be completely oxidized, which increases the oxidation rate of organic compounds and makes the oxidation reaction proceed more completely. However, if the water sample contains $\mathrm{Cl}^{-}$, it will combine with $\mathrm{Ag}^{+}$to produce $\mathrm{AgCl}$ precipitate, resulting in poisoning of the catalyst, then decreasing the oxidation rate of the sample, and finally affecting the final determination results of COD. The reaction between $\mathrm{Cl}^{-}$and $\mathrm{Ag}_{2} \mathrm{SO}_{4}$ is expressed as follows:

$$
\mathrm{Ag}_{2} \mathrm{SO}_{4}+2 \mathrm{Cl}^{-} \rightarrow 2 \mathrm{AgCl} \downarrow+\mathrm{SO}_{4}^{2-}\left(K_{s p}=1.77 \times 10^{-10}, 25^{\circ} \mathrm{C}\right)
$$

In addition, the resulting $\mathrm{AgCl}$ precipitate can be further oxidized by $\mathrm{K}_{2} \mathrm{Cr}_{2} \mathrm{O}_{7}$, which also consumes some oxidants. Moreover, the white precipitate makes the 
solution color at the end of titration become grey and difficult to be titrated accurately.

\subsection{Reducing Interferences of $\mathrm{Cl}^{-}$on $\mathrm{COD}_{\mathrm{Cr}}$ Determination in High Chloride Oilfield Wastewater}

\subsubsection{Theoretical Analysis of Reducing $\mathrm{Cl}^{-}$Interference}

During the COD determination, the interference reaction $\mathrm{fl}^{-}$is as follows:

$$
\mathrm{Cr}_{2} \mathrm{O}_{7}^{2-}+14 \mathrm{H}^{+}+6 \mathrm{Cl}^{-}=2 \mathrm{Cr}^{3+}+7 \mathrm{H}_{2} \mathrm{O}+3 \mathrm{Cl}_{2} \uparrow
$$

In Equation (3), the electrode reaction of electron pair $\mathrm{Cr}_{2} \mathrm{O}_{7}^{2-} / \mathrm{Cr}^{3+}$ is:

$$
\mathrm{Cr}_{2} \mathrm{O}_{7}^{2-}+14 \mathrm{H}^{+}+6 e^{-}=2 \mathrm{Cr}^{3+}+7 \mathrm{H}_{2} \mathrm{O}
$$

And the electrode reaction of electron pair $\mathrm{Cl}_{2} / \mathrm{Cl}^{-}$is:

$$
\mathrm{Cl}_{2}+2 e^{-}=2 \mathrm{Cl}^{-}
$$

According to the Nernst equation, the electrode potential of electron pair $\mathrm{Cr}_{2} \mathrm{O}_{7}^{2-} / \mathrm{Cr}^{3+}$ can be calculated as follows:

$$
\begin{aligned}
\varphi_{\mathrm{Cr}_{2} \mathrm{O}_{7}^{2}-/ \mathrm{Cr}^{3+}} & =\varphi_{\mathrm{Cr}_{2} \mathrm{O}_{7}^{2-} / \mathrm{Cr}^{3+}}^{\theta}+\frac{R T}{n F} \ln \frac{\alpha_{\mathrm{Cr}_{2} \mathrm{O}_{7}^{2}} \cdot \alpha_{\mathrm{H}^{+}}^{14}}{\alpha_{\mathrm{Cr}^{3+}}^{2}} \\
& =\varphi_{\mathrm{Cr}_{2} \mathrm{O}_{7}^{2-} / \mathrm{Cr}^{3+}}^{\theta}+\frac{R T}{n F} \ln \alpha_{\mathrm{H}^{+}}^{14}+\frac{R T}{n F} \ln \frac{\alpha_{\mathrm{Cr}_{2} \mathrm{O}_{7}^{--}}}{\alpha_{\mathrm{Cr}^{3+}}^{2}}
\end{aligned}
$$

Similarly, the electrode potential of electron pair $\mathrm{Cl}_{2} / \mathrm{Cl}^{-}$can be calculated as:

$$
\varphi_{\mathrm{Cl}_{2} / \mathrm{Cl}^{-}}=\varphi_{\mathrm{Cl}_{2} / \mathrm{Cl}^{-}}^{\theta}+\frac{R T}{n F} \ln \frac{p_{\mathrm{Cl}_{2} / p^{\theta}}}{\alpha_{\mathrm{Cl}^{-}}^{2}}
$$

In the determination of $\mathrm{COD}_{\mathrm{Cr}}$, the conditional electrode potential of oxidant $\mathrm{K}_{2} \mathrm{Cr}_{2} \mathrm{O}_{7}$ can reach to $\varphi_{\mathrm{Cr}_{2} \mathrm{O}_{7}^{2-} / \mathrm{Cr}^{3+}}=1.55 \mathrm{~V}$ due to the strong acid medium (in non strong acid medium $\left.\varphi_{\mathrm{Cr}_{2} \mathrm{O}_{7}^{-2} / \mathrm{Cr}^{3+}}=1.33 \mathrm{~V}\right)$ [20], thus the oxidation reaction of $\mathrm{Cl}^{-}$can occur completely $\left(\varphi_{\mathrm{Cl}_{2} / \mathrm{Cl}^{-}}=1.36 \mathrm{~V}\right)$. And the higher the oxidation potential is, the easier the $\mathrm{Cl}^{-}$will be oxidized, and consequently the greater the error introduced is.

As can be known from Equation (6), the concentration of $\mathrm{Cr}_{2} \mathrm{O}_{7}^{2-}$ and $\mathrm{Cr}^{3+}$ is one of the main factors that affect the electrode potential. Under certain conditions of $\mathrm{COD}_{\mathrm{Cr}}$ determination, the higher the oxidant concentration is, the more residual amount of oxidant will be after the reaction, which makes the ratio of $\mathrm{Cr}_{2} \mathrm{O}_{7}^{2-} / \mathrm{Cr}^{3+}$ larger, and results in a higher oxidation potential. Theoretically speaking, the proper reduction of the oxidant concentration is helpful to reduce the oxidation potential of $\mathrm{K}_{2} \mathrm{Cr}_{2} \mathrm{O}_{7}$ and thus reduce the interferences of $\mathrm{Cl}^{-}$on $\mathrm{COD}_{\mathrm{Cr}}$ determination.

\subsubsection{Effect of Oxidant Concentration on the Oxidation of $\mathrm{Cl}^{-}$}

In order to investigate the effect of oxidant concentration on $\mathrm{Cl}^{-}$oxidation, a series of $\mathrm{NaCl}$ solutions with $\mathrm{Cl}^{-}$mass concentrations of 1000, 2000, 4000, 8000, 15,000 and $20,000 \mathrm{mg} \cdot \mathrm{L}^{-1}$ were prepared by standard $\mathrm{NaCl} .20 \mathrm{~mL}$ of each water sample was transferred into a COD digestion tube, then appropriate amounts of 
$\mathrm{HgSO}_{4}\left[m\left(\mathrm{HgSO}_{4}\right): m\left(\mathrm{Cl}^{-}\right)=10: 1\right]$ were added to the sample solution, and finally the mixture of each water was oxidized with $10 \mathrm{~mL}$ of $0.25,0.1$ and $0.025 \mathrm{~mol} \cdot \mathrm{L}^{-1}$ $\mathrm{K}_{2} \mathrm{Cr}_{2} \mathrm{O}_{7}$ standard solution, respectively. After heating reflux for about $2 \mathrm{~h}$, the residual content of $\mathrm{K}_{2} \mathrm{Cr}_{2} \mathrm{O}_{7}$ was back titrated by corresponding $0.1,0.04$ and $0.01 \mathrm{~mol} \cdot \mathrm{L}^{-1}\left[\left(\mathrm{NH}_{4}\right)_{2} \mathrm{Fe}\left(\mathrm{SO}_{4}\right)_{2} \cdot 6 \mathrm{H}_{2} \mathrm{O}\right]$ standard solution, respectively. The obtained $\mathrm{COD}_{\mathrm{Cr}}$ results in the prepared water samples are plotted in Figure 1.

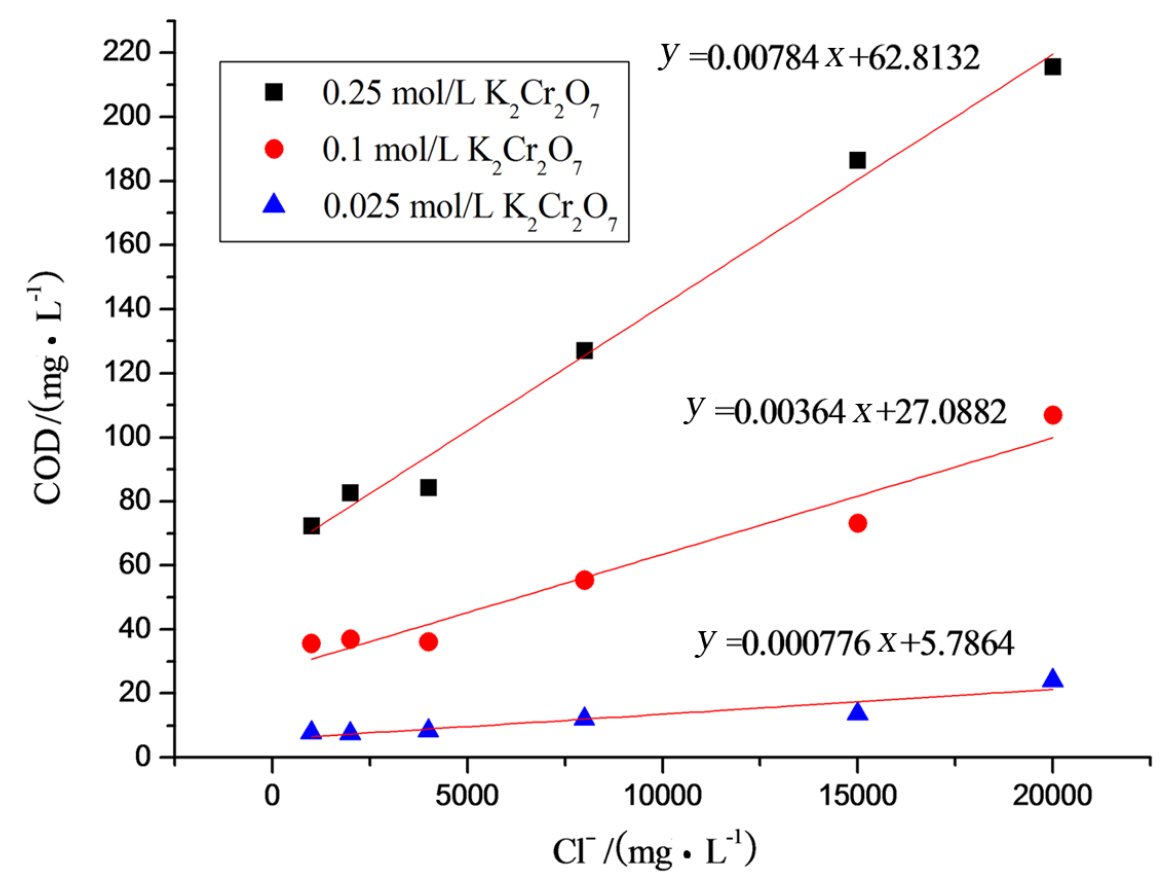

Figure 1. Effect of oxidant concentration on the oxidation of $\mathrm{Cl}^{-}$.

As can be seen from Figure 1, on the one hand, under the same $\mathrm{Cl}^{-}$mass concentration, both the oxidation rate of $\mathrm{Cl}^{-}$and obtained $\mathrm{COD}_{\mathrm{Cr}}$ values increased gradually with the increase of oxidant concentration; on the other hand, under the same oxidant concentration, the obtained $\mathrm{COD}_{\mathrm{Cr}}$ values and their relative errors also increased gradually with the increase of $\mathrm{Cl}^{-}$concentration. When the oxidant concentration was about $0.025 \mathrm{~mol} \cdot \mathrm{L}^{-1}$, the oxidation rate of $\mathrm{Cl}^{-}$was the smallest. These results indicated that the oxidant concentration plays an very important role during the determination of COD in high chloride wastewater. Therefore, the proper reduction of oxidant concentration is helpful to reduce the oxidation rate of $\mathrm{Cl}^{-}$and improve the accuracy of $\mathrm{COD}_{\mathrm{Cr}}$ determination, which is highly consistent with our theoretical analysis in Section 3.2.1.

\subsubsection{Effect of Oxidant Concentration on the Oxidation of Organic Compounds}

In order to investigate the effect of oxidant concentration on the oxidation of organic compounds, a series of standard $\mathrm{KC}_{8} \mathrm{H}_{5} \mathrm{O}_{4}$ solutions with theoretical $\mathrm{COD}_{\mathrm{Cr}}$ values of $50,100,300$ and $600 \mathrm{mg} \cdot \mathrm{L}^{-1}$ were prepared by standard $\mathrm{KC}_{8} \mathrm{H}_{5} \mathrm{O}_{4}$. After proper dilution, $20 \mathrm{~mL}$ of each water sample was transferred into a COD digestion tube, then $30 \mathrm{~mL} \mathrm{AgSO}-\mathrm{H}_{2} \mathrm{SO}_{4}$ was added to the sample so- 
lution, and finally the mixture of each water was oxidized with $10 \mathrm{~mL}$ of $0.25,0.1$ and $0.025 \mathrm{~mol} \cdot \mathrm{L}^{-1} \mathrm{~K}_{2} \mathrm{Cr}_{2} \mathrm{O}_{7}$ standard solution, respectively. After heating reflux for about $2 \mathrm{~h}$, the residual content of $\mathrm{K}_{2} \mathrm{Cr}_{2} \mathrm{O}_{7}$ was back titrated by corresponding $0.1,0.04$ and $0.01 \mathrm{~mol} \cdot \mathrm{L}^{-1}\left[\left(\mathrm{NH}_{4}\right)_{2} \mathrm{Fe}\left(\mathrm{SO}_{4}\right)_{2} \cdot 6 \mathrm{H}_{2} \mathrm{O}\right]$ standard solution, respectively. The obtained $\mathrm{COD}_{\mathrm{Cr}}$ results in the prepared water samples are summarized in Table 3.

Table 3. Effect of oxidant concentration on COD determination of standard $\mathrm{KC}_{8} \mathrm{H}_{5} \mathrm{O}_{4}$ water samples.

\begin{tabular}{ccccccc}
\hline $\begin{array}{c}\text { Theoretical } \\
\mathrm{COD} /\left(\mathrm{mg} \cdot \mathrm{L}^{-1}\right)\end{array}$ & $\begin{array}{c}\text { Dilution } \\
\text { fold }\end{array}$ & $\begin{array}{c}0.25 \mathrm{~mol} \cdot \mathrm{L}^{-1} \\
\mathrm{~K}_{2} \mathrm{Cr}_{2} \mathrm{O}_{7} \\
\mathrm{COD} /\left(\mathrm{mg} \cdot \mathrm{L}^{-1}\right)\end{array}$ & $\begin{array}{c}\text { Dilution } \\
\text { fold }\end{array}$ & $\begin{array}{c}0.1 \mathrm{~mol} \cdot \mathrm{L}^{-1} \\
\mathrm{~K}_{2} \mathrm{Cr}_{2} \mathrm{O}_{7} \\
\mathrm{COD} /\left(\mathrm{mg} \cdot \mathrm{L}^{-1}\right)\end{array}$ & $\begin{array}{c}\text { Dilution } \\
\text { fold }\end{array}$ & $\begin{array}{c}0.025 \mathrm{~mol} \cdot \mathrm{L}^{-1} \\
\mathrm{~K}_{2} \mathrm{Cr}_{2} \mathrm{O}_{7} \\
\mathrm{COD} /\left(\mathrm{mg} \cdot \mathrm{L}^{-1}\right)\end{array}$ \\
\hline 50 & 1 & 51.0 & 1 & 54.6 & 1 & 48.1 \\
100 & 1 & 97.3 & 1 & 100.8 & 2 & 93.9 \\
300 & 1 & 299.8 & 1 & 299.5 & 5 & 286.0 \\
600 & 1 & 596.8 & 2 & 602.1 & 10 & 583.3 \\
\hline
\end{tabular}

Table 3 revealed that under the same condition of $\mathrm{COD}_{\mathrm{Cr}}$ determination, different concentrations of oxidants exhibit almost the same oxidation ability on the standard $\mathrm{KC}_{8} \mathrm{H}_{5} \mathrm{O}_{4}$, and the measured $\mathrm{COD}_{\mathrm{Cr}}$ values are nearly consistent with the theoretical ones. In addition, with the increase of theoretical $\mathrm{COD}_{\mathrm{Cr}}$ value in the samples, the measured results by different concentrations of oxidants are almost the same, which implied that the concentration of oxidant has little effect on the oxidation of organic compounds as long as the amount of $\mathrm{K}_{2} \mathrm{Cr}_{2} \mathrm{O}_{7}$ is enough.

\subsubsection{Effect of the Amount of Masking Agent on COD $\mathrm{Cr}_{\mathrm{rr}}$ Determination}

In order to investigate the effect of the amount of masking agent on $\mathrm{COD}_{\mathrm{Cr}}$ determination, in this part, a series of standard water samples with a theoretical $\mathrm{COD}_{\mathrm{Cr}}$ value of $500 \mathrm{mg} \cdot \mathrm{L}^{-1}$ and $\mathrm{Cl}^{-}$mass concentrations of 1000, 2000, 4000, $8000,15,000$ and $20,000 \mathrm{mg} \cdot \mathrm{L}^{-1}$ were prepared by standard $\mathrm{KC}_{8} \mathrm{H}_{5} \mathrm{O}_{4}$ and standard $\mathrm{NaCl}$. After 10-folds dilution, $20 \mathrm{~mL}$ of each water sample was transferred into a COD digestion tube, then different amounts of $\mathrm{HgSO}_{4}$ based on the mass ratio of $\mathrm{HgSO}_{4}: \mathrm{Cl}^{-}$together with $30 \mathrm{~mL} \mathrm{AgSO}{ }_{4}-\mathrm{H}_{2} \mathrm{SO}_{4}$ were added to the sample solution, and finally the mixture of each water was oxidized with $10 \mathrm{~mL}$ of 0.25 mol. $\mathrm{L}^{-1} \mathrm{~K}_{2} \mathrm{Cr}_{2} \mathrm{O}_{7}$ standard solution. After heating reflux for about $2 \mathrm{~h}$, the residual content of $\mathrm{K}_{2} \mathrm{Cr}_{2} \mathrm{O}_{7}$ was back titrated by corresponding $0.1 \mathrm{~mol} \cdot \mathrm{L}^{-1}$ $\left[\left(\mathrm{NH}_{4}\right)_{2} \mathrm{Fe}\left(\mathrm{SO}_{4}\right)_{2} \cdot 6 \mathrm{H}_{2} \mathrm{O}\right]$ standard solution. The obtained $\mathrm{COD}_{\mathrm{Cr}}$ results in the prepared water samples are summarized in Table 4.

As can be seen from Table 4 , the relative errors of $\mathrm{COD}_{\mathrm{Cr}}$ results decreased gradually with the increase of the mass ratio of $\mathrm{HgSO}_{4}: \mathrm{Cl}^{-}$. When the mass ratio of $\mathrm{HgSO}_{4}: \mathrm{Cl}^{-}$is $10: 1$, the relative errors are small $(< \pm 3 \%)$, and they are not significantly improved with the increase of the mass ratio of $\mathrm{HgSO}_{4}: \mathrm{Cl}^{-}$. However, the environmental pollution risk would increase if large amounts of $\mathrm{HgSO}_{4}$ were used. Therefore, 10:1 was suggested to be the suitable mass ratio of $\mathrm{HgSO}_{4}: \mathrm{Cl}^{-}$ for $\mathrm{COD}_{\mathrm{Cr}}$ determination in high chlorine wastewater. 
Table 4. Effect of mass ratio of $\mathrm{HgSO}_{4}: \mathrm{Cl}^{-}$on $\mathrm{COD}_{\mathrm{Cr}}$ determination in high chlorine water samples.

\begin{tabular}{cccccr}
\hline Sample No. & $\mathrm{Cl}^{-}$content/(mg.L $\left.{ }^{-1}\right)$ & $5: 1$ & $10: 1$ & $15: 1$ & \multicolumn{1}{c}{$20: 1$} \\
\hline 1 & 1000 & $500.0[0 \%]^{*}$ & $511.2[2.2 \%]$ & $495.6[-0.9 \%]$ & $484.0[-3.2 \%]$ \\
2 & 2000 & $507.2[1.4 \%]$ & $514.4[2.9 \%]$ & $508.0[1.6 \%]$ & $510.4[2.1 \%]$ \\
3 & 4000 & $519.6[3.9 \%]$ & $495.6[-0.9 \%]$ & $502.4[0.5 \%]$ & $492.0[-1.6 \%]$ \\
4 & 8000 & $558.4[11.7 \%]$ & $511.6[2.3 \%]$ & $532.0[6.4 \%]$ & $516.0[3.2 \%]$ \\
5 & 15,000 & $567.2[13.4 \%]$ & $508.4[1.7 \%]$ & $520.0[4.0 \%]$ & $512.8[2.6 \%]$ \\
6 & 20,000 & $551.2[10.2 \%]$ & $514.8[3.0 \%]$ & $520.0[4.0 \%]$ & $520.0[4.0 \%]$ \\
\hline
\end{tabular}

${ }^{*}$ The values in bracket are the relative errors and the same meanings in Table 5 and Table 6.

\subsection{Determination of $\mathrm{COD}_{\mathrm{Cr}}$ in High Chlorine Oilfield Wastewater by Low Concentration Oxidant Method}

\subsubsection{Determination of Low $\operatorname{COD}_{\mathrm{Cr}}$ in Simulated High Chloride Oilfield Wastewater by Low Concentration Oxidant Method}

A series of simulated high chlorine oilfield wastewater samples with theoretical $\mathrm{COD}_{\mathrm{Cr}}$ values of 50 and $80 \mathrm{mg} \cdot \mathrm{L}^{-1}$, and $\mathrm{Cl}^{-}$mass concentrations of 1000,2000 , $4000,8000,15,000$ and 20,000 mg. $\mathrm{L}^{-1}$ were prepared by standard $\mathrm{KC}_{8} \mathrm{H}_{5} \mathrm{O}_{4}$ and standard $\mathrm{NaCl}$. According to the classical $\mathrm{K}_{2} \mathrm{Cr}_{2} \mathrm{O}_{7}$ method, $20 \mathrm{~mL}$ of each water sample was transferred into a $\mathrm{COD}$ digestion tube, then appropriate amounts of $\mathrm{HgSO}_{4}\left[m\left(\mathrm{HgSO}_{4}\right): m\left(\mathrm{Cl}^{-}\right)=10: 1\right]$ and $30 \mathrm{~mL} \mathrm{AgSO}_{4}-\mathrm{H}_{2} \mathrm{SO}_{4}$ were added to the sample solution, and finally the mixture of each wastewater was oxidized with $10 \mathrm{~mL}$ of $0.25 \mathrm{~mol} \cdot \mathrm{L}^{-1}, 0.1 \mathrm{~mol} \cdot \mathrm{L}^{-1}$ and $0.025 \mathrm{~mol} \cdot \mathrm{L}^{-1} \mathrm{~K}_{2} \mathrm{Cr}_{2} \mathrm{O}_{7}$ standard solution, respectively. After heating reflux for about $2 \mathrm{~h}$, the residual content of $\mathrm{K}_{2} \mathrm{Cr}_{2} \mathrm{O}_{7}$ was back titrated by corresponding $0.1,0.04$ and 0.01 mol. $\cdot \mathrm{L}^{-1}\left[\left(\mathrm{NH}_{4}\right)_{2} \mathrm{Fe}\left(\mathrm{SO}_{4}\right)_{2} \cdot 6 \mathrm{H}_{2} \mathrm{O}\right]$ standard solution, respectively. The obtained $\mathrm{COD}_{\mathrm{Cr}}$ results in the simulated high chlorine oilfield wastewater samples are summarized in Table 5.

Table 5. Determination results of high chlorine and low COD simulated oilfield wastewater using different concentrations of oxidants.

\begin{tabular}{|c|c|c|c|c|c|}
\hline $\begin{array}{l}\text { Sample } \\
\text { No. }\end{array}$ & $\begin{array}{c}\mathrm{Cl}^{-} \\
\left.\text {content/(mg. } \mathrm{L}^{-1}\right)\end{array}$ & $\begin{array}{c}\text { Theoretical } \\
\mathrm{COD} /\left(\mathrm{mg} \cdot \mathrm{L}^{-1}\right)\end{array}$ & $\begin{array}{c}0.25 \mathrm{~mol} \cdot \mathrm{L}^{-1} \\
\mathrm{~K}_{2} \mathrm{Cr}_{2} \mathrm{O}_{7} \\
\mathrm{COD} /\left(\mathrm{mg} \cdot \mathrm{L}^{-1}\right)\end{array}$ & $\begin{array}{c}0.1 \mathrm{~mol} \cdot \mathrm{L}^{-1} \\
\mathrm{~K}_{2} \mathrm{Cr}_{2} \mathrm{O}_{7} \\
\mathrm{COD} /\left(\mathrm{mg} \cdot \mathrm{L}^{-1}\right)\end{array}$ & $\begin{array}{c}0.025 \mathrm{~mol} \cdot \mathrm{L}^{-1} \\
\mathrm{~K}_{2} \mathrm{Cr}_{2} \mathrm{O}_{7} \\
\mathrm{COD} /\left(\mathrm{mg} \cdot \mathrm{L}^{-1}\right)\end{array}$ \\
\hline 1 & \multirow{2}{*}{1000} & 50 & 118.4 [136.8\%] & 77.3 [54.6\%] & $45.7[-8.5 \%]$ \\
\hline 2 & & 80 & 156.4 [95.5\%] & 109.4 [36.7\%] & $79.3[-0.9 \%]$ \\
\hline 3 & \multirow{2}{*}{2000} & 50 & $138.2[176.4 \%]$ & 83.8 [67.6\%] & $47.1[-5.8 \%]$ \\
\hline 4 & & 80 & 159.9 [99.9\%] & 110.6 [38.3\%] & $80.4[0.5 \%]$ \\
\hline 5 & \multirow{2}{*}{4000} & 50 & 170.3 [240.6\%] & 94.2 [88.4\%] & $50.8[1.7 \%]$ \\
\hline 6 & & 80 & $187.4[134.2 \%]$ & 120.0 [50.0\%] & 81.7 [2.1\%] \\
\hline 7 & \multirow{2}{*}{8000} & 50 & 166.3 [232.6\%] & 92.0 [84.1\%] & $49.3[-1.5 \%]$ \\
\hline 8 & & 80 & 211.3 [164.1\%] & 115.4 [44.3\%] & 80.9 [1.2\%] \\
\hline 9 & \multirow{2}{*}{15,000} & 50 & 183.3 [266.7\%] & 91.4 [82.8\%] & $51.5[3.0 \%]$ \\
\hline 10 & & 80 & 226.6 [183.2\%] & 118.2 [47.8\%] & $83.6[4.5 \%]$ \\
\hline 11 & \multirow{2}{*}{20,000} & 50 & $174.6[249.3 \%]$ & 85.2 [70.4\%] & $50.0[0.0 \%]$ \\
\hline 12 & & 80 & $215.2[169.0 \%]$ & 109.4 [36.7\%] & 82.8 [3.5\%] \\
\hline
\end{tabular}


Table 5 shows that with the increase of $\mathrm{Cl}^{-}$mass concentration in wastewater samples, the relative errors of $\mathrm{COD}_{\mathrm{Cr}}$ determination increased gradually. However, the obtained results provided by low concentration oxidant method $(0.025$ $\mathrm{mol} \cdot \mathrm{L}^{-1}$ ) are much better than those determined by $0.25 \mathrm{~mol} \cdot \mathrm{L}^{-1}$ and $0.1 \mathrm{~mol} \cdot \mathrm{L}^{-1}$ oxidants, and the relative errors conform to the national requirements for $\mathrm{COD}_{\mathrm{Cr}}$ determination. These experimental results demonstrated that low concentration oxidant method is feasible for the determination of low $\mathrm{COD}_{\mathrm{Cr}}$ in high chlorine wastewater when $\mathrm{Cl}^{-}$concentration is not more than $20000 \mathrm{mg} \cdot \mathrm{L}^{-1}$ and $\mathrm{COD}<100 \mathrm{mg} \cdot \mathrm{L}^{-1}$.

\subsubsection{Determination of High $\mathrm{COD}_{\mathrm{Cr}}$ in Simulated High Chloride Oilfield Wastewater by Low Concentration Oxidant Method}

It can be inferred from the above experimental results that the determination of high $\mathrm{COD}_{\mathrm{Cr}}$ in high chlorine wastewater is also possible by low concentration oxidant method. In order to verify this inference, a series of simulated high chlorine oilfield wastewater samples with theoretical $\mathrm{COD}_{\mathrm{Cr}}$ values of 500, 1000 and $3000 \mathrm{mg} \cdot \mathrm{L}^{-1}$, and $\mathrm{Cl}^{-}$mass concentrations of 5000, 10,000, 50,000, 10,000 and $200,000 \mathrm{mg} \cdot \mathrm{L}^{-1}$ were prepared by standard $\mathrm{KC}_{8} \mathrm{H}_{5} \mathrm{O}_{4}$ and standard $\mathrm{NaCl}$. After proper dilution, $20 \mathrm{~mL}$ of each water sample was transferred into a COD digestion tube, then appropriate amounts of $\mathrm{HgSO}_{4}\left[m\left(\mathrm{HgSO}_{4}\right): m\left(\mathrm{Cl}^{-}\right)=10: 1\right]$ and $30 \mathrm{~mL} \mathrm{AgSO}{ }_{4}-\mathrm{H}_{2} \mathrm{SO}_{4}$ were added to the sample solution, and finally the mixture of each wastewater was oxidized with $10 \mathrm{~mL}$ of $0.025 \mathrm{~mol} \cdot \mathrm{L}^{-1} \mathrm{~K}_{2} \mathrm{Cr}_{2} \mathrm{O}_{7}$ standard solution. After heating reflux for about $2 \mathrm{~h}$, the residual content of $\mathrm{K}_{2} \mathrm{Cr}_{2} \mathrm{O}_{7}$ was back titrated by $0.01 \mathrm{~mol} \cdot \mathrm{L}^{-1}\left[\left(\mathrm{NH}_{4}\right)_{2} \mathrm{Fe}\left(\mathrm{SO}_{4}\right)_{2} \cdot 6 \mathrm{H}_{2} \mathrm{O}\right]$ standard solution. The obtained $\mathrm{COD}_{\mathrm{Cr}}$ results in the simulated high chlorine oilfield wastewater samples are summarized in Table 6.

Table 6. Determination results of high chlorine and high COD simulated oilfield wastewater by low concentration oxidant method.

\begin{tabular}{cccccccc}
\hline $\begin{array}{c}\text { Sample } \\
\text { No. }\end{array}$ & $\begin{array}{c}\mathrm{Cl}^{-} \\
\text {content/ } \\
\left(\mathrm{mg} \cdot \mathrm{L}^{-1}\right)\end{array}$ & $\begin{array}{c}\text { Dilution } \\
\text { fold }\end{array}$ & $\begin{array}{c}\text { Theor. COD } \\
500 \mathrm{mg} \cdot \mathrm{L}^{-1} / \\
\left(\mathrm{mg} \cdot \mathrm{L}^{-1}\right)\end{array}$ & $\begin{array}{c}\text { Dilution } \\
\text { fold }\end{array}$ & $\begin{array}{c}\text { Theor. COD } \\
1000 \mathrm{mg} \cdot \mathrm{L}^{-1} / \\
\left(\mathrm{mg} \cdot \mathrm{L}^{-1}\right)\end{array}$ & $\begin{array}{c}\text { Dilution } \\
\text { fold }\end{array}$ & $\begin{array}{c}\text { Theor. COD } \\
3000 \mathrm{mg} \cdot \mathrm{L}^{-1} / \\
\left(\mathrm{mg} \cdot \mathrm{L}^{-1}\right)\end{array}$ \\
\hline 1 & 5000 & 10 & $487.3[-2.5 \%]$ & 20 & $992.3[-0.8 \%]$ & 60 & $2887.7[-3.7 \%]$ \\
2 & 10000 & 10 & $507.5[1.5 \%]$ & 20 & $975.4[-2.5 \%]$ & 60 & $3045.6[1.5 \%]$ \\
3 & 50000 & 10 & $528.1[5.6 \%]$ & 20 & $999.9[0.0 \%]$ & 60 & $3084.0[2.8 \%]$ \\
4 & 100,000 & 10 & $537.8[7.6 \%]$ & 20 & $1026.1[2.6 \%]$ & 60 & $3094.9[3.2 \%]$ \\
5 & 200,000 & 10 & $525.2[5.0 \%]$ & 20 & $10,333.7[3.4 \%]$ & 60 & $3099.7[3.3 \%]$ \\
\hline
\end{tabular}

As can be seen from Table 6, the low concentration oxidant method provides relatively small errors for the determination of high $\mathrm{COD}_{\mathrm{Cr}}$ in high chlorine wastewater, and the obtained results are accurate and reliable. The above experiments proved that it is feasible to determine $\mathrm{COD}_{\mathrm{Cr}}$ (including both low $\mathrm{COD}$ and high COD) in high chlorine wastewater by low concentration oxidant method. Therefore, in the next part, we intend to extend the low concentration 
oxidant method to determine the $\mathrm{COD}_{\mathrm{Cr}}$ values in actual high chloride oilfield wastewater.

\subsubsection{Determination of $\mathrm{COD}_{\mathrm{Cr}}$ in Actual High Chloride Oilfield Wastewater by Low Concentration Oxidant Method}

Six kinds of oilfield wastewater samples named JHSX, JHCL, XJ81J, XJ81C, XJ91J and XJ91C were collected from Jianghan oilfield and Xinjiang oilfield, China. The $\mathrm{Cl}^{-}$contents in the six wastewater samples are 92,744.4, 74,155.4, $7578.5,7699.7,2086.8$ and $2273 \mathrm{mg} \cdot \mathrm{L}^{-1}$, respectively, which were determined by a Thermo Fisher ICS-2100 ion chromatograph. It clearly shows that these wastewater samples belong to typical high chloride oilfield wastewater. Therefore, in this section, the $\mathrm{COD}_{\mathrm{Cr}}$ values in these six high chloride oilfield wastewater samples were determined by the proposed low concentration oxidant method. According to the low concentration of oxidant method, each wastewater sample was diluted 10 -folds and $20 \mathrm{~mL}$ of diluted wastewater sample was transferred into a COD digestion tube, then appropriate amounts of $\mathrm{HgSO}_{4}$ [ $\left.m\left(\mathrm{HgSO}_{4}\right): m\left(\mathrm{Cl}^{-}\right)=10: 1\right]$ and $30 \mathrm{~mL} \mathrm{AgSO}{ }_{4}-\mathrm{H}_{2} \mathrm{SO}_{4}$ were added to the sample solution, and finally the mixture of each wastewater was oxidized with 0.025 mol. $\mathrm{L}^{-1} \mathrm{~K}_{2} \mathrm{Cr}_{2} \mathrm{O}_{7}$ standard solution. After heating reflux, the residual content of $\mathrm{K}_{2} \mathrm{Cr}_{2} \mathrm{O}_{7}$ was back titrated by corresponding $0.01 \mathrm{~mol} \cdot \mathrm{L}^{-1}\left[\left(\mathrm{NH}_{4}\right)_{2} \mathrm{Fe}\left(\mathrm{SO}_{4}\right)_{2} \cdot 6 \mathrm{H}_{2} \mathrm{O}\right]$ standard solution. The obtained $\mathrm{COD}_{\mathrm{Cr}}$ results in the six kinds of actual high chloride oilfield wastewater samples are summarized in Table 7.

Table 7. Determination results of $\mathrm{COD}_{\mathrm{Cr}}$ in six actual high chloride oilfield wastewater samples by low concentration oxidant method.

\begin{tabular}{ccccccc}
\hline $\begin{array}{c}\text { Sample } \\
\text { No. }\end{array}$ & $\begin{array}{c}\text { Water } \\
\text { sample }\end{array}$ & $\begin{array}{c}\mathrm{Cl}^{-} / \\
\left(\mathrm{mg} \cdot \mathrm{L}^{-1}\right)\end{array}$ & Dilution fold & $\begin{array}{c}\text { Unspiked COD/ } \\
\left(\mathrm{mg} \cdot \mathrm{L}^{-1}\right)\end{array}$ & $\begin{array}{c}\text { Spiked COD/ } \\
\left(\mathrm{mg} \cdot \mathrm{L}^{-1}\right)\end{array}$ & $\begin{array}{c}\text { Spiked } \\
\text { recovery/\% }\end{array}$ \\
\hline 1 & JHSX & $92,744.4$ & 10 & 154.1 & 631.1 & 95.4 \\
2 & JHCL & $74,155.4$ & 10 & 150.5 & 630.3 & 96.0 \\
3 & XJ81J & 7578.5 & 10 & 109.0 & 641.3 & 106.5 \\
4 & XJ81C & 7699.7 & 10 & 148.2 & 635.0 & 97.4 \\
5 & XJ91J & 2086.8 & 10 & 123.1 & 626.8 & 100.7 \\
6 & XJ91C & 2273.0 & 10 & 87.8 & 606.8 & 103.8 \\
\hline
\end{tabular}

As shown in Table 7, the $\mathrm{COD}_{\mathrm{Cr}}$ values of six kinds of high chloride oilfield wastewater samples are not high, which ranges from 100 to $150 \mathrm{mg} \cdot \mathrm{L}^{-1}$. Furthermore, spiked recovery experiments were carried out to verify the accuracy of low concentration oxidant method for $\mathrm{COD}_{\mathrm{Cr}}$ determination in actual high chloride oilfield wastewater. Firstly, $500 \mathrm{mg} \cdot \mathrm{L}^{-1}$ theoretical $\mathrm{COD}_{\mathrm{Cr}}$ was added to the above six high chloride oilfield wastewater samples, and then the $\mathrm{COD}_{\mathrm{Cr}}$ values of these spiked oilfield wastewater samples were determined by the proposed low concentration oxidant method. The spiked recoveries were calculated as $c_{1} / c_{2} \times$ $100 \%$, where $c_{1}$ is the difference of measured total $\mathrm{COD}_{\mathrm{Cr}}$ value of the spiked oilfield wastewater samples and unspiked oilfield wastewater samples; and $c_{2}$ is the theoretical $\mathrm{COD}_{\mathrm{Cr}}$ value of added standard $\mathrm{KC}_{8} \mathrm{H}_{5} \mathrm{O}_{4}$. The calculated recovery 
results are shown in Table 7 . It can be seen from Table 7 that the spiked $\mathrm{COD}_{\mathrm{Cr}}$ recoveries of six high chloride oilfield wastewater samples measured by the low concentration oxidant method were in the range of 95.4-106.5\%, which revealed that the low concentration oxidant method is feasible and reliable for the determination of $\mathrm{COD}_{\mathrm{Cr}}$ in high chloride oilfield wastewater.

\section{Conclusions}

1) As for high chloride water samples, the $\mathrm{COD}_{\mathrm{Cr}}$ values and their deviations determined by the classical potassium dichromate $\left(\mathrm{K}_{2} \mathrm{Cr}_{2} \mathrm{O}_{7}\right)$ method increased gradually with the increase of $\mathrm{Cl}^{-}$mass concentration. These effect is more obvious in low $\mathrm{COD}_{\mathrm{Cr}}$ wastewater than that of high $\mathrm{COD}_{\mathrm{Cr}}$ wastewater, which revealed that $\mathrm{Cl}^{-}$has serious interferences on the determination of $\mathrm{COD}_{\mathrm{Cr}}$ based on the classical $\mathrm{K}_{2} \mathrm{Cr}_{2} \mathrm{O}_{7}$ method.

2) During the interference analysis, the oxidation abilities of $\mathrm{K}_{2} \mathrm{Cr}_{2} \mathrm{O}_{7}$ on $\mathrm{Cl}^{-}$ decreased as its decreasing concentration, while having little effects on the oxidation of organic compounds. More specifically, when the concentration of $\mathrm{K}_{2} \mathrm{Cr}_{2} \mathrm{O}_{7}$ was $0.025 \mathrm{~mol} \cdot \mathrm{L}^{-1}$, the interferences of $\mathrm{Cl}^{-}$on $\mathrm{COD}_{\mathrm{Cr}}$ determination were the slightest. Therefore, the optimum concentration of $\mathrm{K}_{2} \mathrm{Cr}_{2} \mathrm{O}_{7}$ in this study was identified as $0.025 \mathrm{~mol} \cdot \mathrm{L}^{-1}$ for the determination of $\mathrm{COD}_{\mathrm{Cr}}$ in high chloride oilfield wastewater.

3) The relative errors of $\mathrm{COD}_{\mathrm{Cr}}$ determined by the low concentration $\mathrm{K}_{2} \mathrm{Cr}_{2} \mathrm{O}_{7}$ method were relatively small and the measured results were accurate in simulated and actual high chloride oilfield wastewater. Moreover, like the Chinese national standard GB 11914-89 method, the low concentration $\mathrm{K}_{2} \mathrm{Cr}_{2} \mathrm{O}_{7}$ method is simple and feasible, and thus it is suitable for the analysis of water samples in large numbers, which proved to be a very effective method for the determination of $\mathrm{COD}_{\mathrm{Cr}}$ in high chloride oilfield wastewater.

4) It was found that low concentration oxidant method has higher requirements on experimental conditions and operator levels due to the use of low concentration of oxidant for the determination of $\mathrm{COD}_{\mathrm{Cr}}$ in high chloride oilfield wastewater. Therefore, during the process of testing, skilled operators and strict operations are crucial for the success of experiments.

\section{Acknowledgements}

The authors would like to acknowledge the financial supports from the Open Fund of the HSE Key Laboratory of CNPC (Grant No. 2016D-5006-08), the Hubei Provincial Natural Science Foundation of China (Grant No. 2018CFB165), and the Doctoral Scientific Research Startup Foundation of Yangtze University, China (Grant No. 801090010134).

\section{Conflicts of Interest}

The authors declare no conflicts of interest regarding the publication of this paper. 


\section{References}

[1] Ma, J. (2017) Determination of Chemical Oxygen Demand in Aqueous Samples with Non-Electrochemical Methods. Trends in Environmental Analytical Chemistry, 14, 37-43. https://doi.org/10.1016/j.teac.2017.05.002

[2] State Environmental Protection Administration of China (2002) Water and Wastewater Monitoring and Analysis Methods. 4th Edition, China Environmental Science Press, Beijing, 210-213.

[3] Li, J., Luo, G., He, L., Xu, J. and Lyu, J. (2018) Analytical Approaches for Determining Chemical Oxygen Demand in Water Bodies: A Review. Critical Reviews in Analytical Chemistry, 48, 47-65. https://doi.org/10.1080/10408347.2017.1370670

[4] Vaidya, B., Watson, S.W., Coldiron, S.J. and Porter, M.D. (1997) Reduction of Chloride Ion Interference in Chemical Oxygen Demand (COD) Determinations Using Bismuth-Based Adsorbents. Analytica Chimica Acta, 357, 167-175. https://doi.org/10.1016/S0003-2670(97)00541-2

[5] Vyrides, I. and Stuckey, D.C. (2009) A Modified Method for the Determination of Chemical Oxygen Demand (COD) for Samples with High Salinity and Low Organics. Bioresource Technology, 100, 979-982. https://doi.org/10.1016/j.biortech.2008.06.038

[6] National Standard of the People's Republic of China. Water Quality-Determination of Chemical Oxygen Demand-Dichromate Method (GB 11914-89).

[7] Chen, P., Zhang, S.H., Lin, N.X. and Chen, W. (2016) Determination of COD in Wastewater Discharged from the Softener in Produced Water of an Oilfield in Xinjiang. Journal of Yangtze University (Natural Section Edition), 13, 1-6.

[8] National Standard of the People's Republic of China. Pollutant Discharge Standard of Urban Sewage Treatment Plant (GB 18918-2002).

[9] Geerdink, R.B., van den Hurk, R.S. and Epema, O.J. (2017) Chemical Oxygen Demand: Historical Perspectives and Future Challenges. Analytica Chimica Acta, 961, 1-11. https://doi.org/10.1016/j.aca.2017.01.009

[10] Baumann, F.J. (1974) Dichromate Reflux Chemical Oxygen Demand. Proposed Method for Chloride Correction in Highly Saline Wastes. Analytical Chemistry, 46, 1336-1338. https://doi.org/10.1021/ac60345a039

[11] Wang, H., Xu, X.L., Han, Y., Le, C. and Zhang, H.Y. (2017) Determination of COD in Effluent with High Chloride from Nanofiltration Membrane for Landfill Leachate Treatment by Chlorine Emendation Method. China Water \& Wastewater, 33, 115-117.

[12] Ma, Y.Y., He, H.J., Yuan, H.Y., Zhang, X.G. and Zhang, X. (2013) Low Concentration COD Analysis Method for Low Concentration of High Chloride Ion Drilling Wastewater in Oil and Gas Field. Henan Chemical Industry, 30, 57-59.

[13] Domini, C.E., Hidalgo, M., Marken, F. and Canals, A. (2006) Comparison of Three Optimized Digestion Methods for Rapid Determination of Chemical Oxygen Demand: Closed Microwaves, Open Microwaves and Ultrasound Irradiation. Analytica Chimica Acta, 561, 210-217. https://doi.org/10.1016/j.aca.2006.01.022

[14] Yang, H.H., Bu, X.B. and Zhang, T. (2015) Research on the Methods for Eliminating the Interference of Chlorine Ion in COD Determination. Shandong Chemical Industry, 4, 53-54.

[15] Environmental Protection Industry Standard of the People's Republic of China, Water quality-Determination of Chemical Oxygen Demand-Fast Digestion Spectrophotometric Method (HJ/T 399-2007). 
[16] Environmental Protection Industry Standard of the People's Republic of China, High-Chlorine Wastewater-Determination of Chemical Oxygen Demand-Chlorine Emendation Method (HJ/T 70-2001).

[17] Environmental Protection Industry Standard of the People's Republic of China, High-Chlorine Wastewater-Determination of Chemical Oxygen Demand-Potassium Iodide Alkaline Permanganate Method (HJ/T 132-2003).

[18] Chen, G.M. and Zhou, X.L. (2012) Discussion on Determination Methods of COD Concentration in Wastewater Containing High Chloride. Industrial Water \& Wastewater, 43, 85-87.

[19] Liu, X.Y., Zhang, D. and Qi, C.W. (2014) New Methods and Research Progress on Determination of Chemical Oxygen Demand. Guangdong Chemical Industry, 41, 53-54.

[20] Lu, F. and Wu, C. (2009) Water Quality COD On-Line Monitoring Instrument and Laboratory Analysis Method Difference Comparison and Analysis. China Resources Comprehensive Utilization, 27, 27-29. 